\title{
AKTIVITAS ANTI BAKTERI DAN ANTI JAMUR SENYAWA CALKON(E)-1-(naftalen-1-il)-3-(naftalen)prop-2-1-on
}

\author{
Rahmiwati Hilma, Jasril, Isnaniar \\ Jurusan Kimia, Universitas Muhammadiyah Riau \\ Jurusan Kimia, Universitas Riau \\ Jurusan Keperawatan, Universitas Muhammadiyah Riau \\ Email: hilma75@yahoo.com
}

\begin{abstract}
ABSTRAK
Pada penelitian ini dilakukan Uji aktivitas antibakteri dan anti jamur terhadap senyawa turunan calkon E)-1-(naftalen-1-il)-3-(naftalen)prop-2-1-on (senyawa A) menggunakan metoda difusi.Bakteri yang digunakan adalah Staphylococcus aureus sebagai bakteri grampositif) dan Escherichia colisebagai bakteri gram negatifdan terhadap senyawa calkon tersebut juga dilakukan uji aktivitas anti jamur menggunakan jamur Candida albicans. Hasil Uji antibakteri terhadap senyawa calkon E)-1-(naftalen-1-il)-3-(naftalen)prop-2-1-on (A) memperlihatkan bahwa senyawa calkon A tidak aktif terlihat dengan tidak adanya zona bening disekitar cakram yang ditetesi dengan sampel calkon. Hasil uji aktivitas antijamur senyawa calkon (E)-1(naftalen-1-il)-3-(naftalen)prop-2-1-on (senyawa A)memperlihatkan aktivitas antijamur yang baik pada konsentrasi $10 \mu \mathrm{g}$ /disk dengan diameter zona hambat yang dihasilkan yaitu sebesar 17, $08 \mathrm{~mm}$
\end{abstract}

Kata Kunci: calkon E)-1-(naftalen-1-il)-3-(naftalen)prop-2-1-on,Antibakteri, Antijamur

\section{PENDAHULUAN}

Saat ini penyakit infeksi menjadi masalah yang serius, ditambah lagi dengan semakin meluasnya resistensi mikroba terhadap obatobatan yang ada. Hal tersebut mendorong pentingnya penggalian sumber obat-obatan antimikroba lain dari bahan alam. Tanaman obat diketahui potensial untuk dikembangkan lebih lanjut pada pengobatan penyakit(Hertiani dkk, 2003).

Penyakit infeksi kulit masih banyak ditemukan pada masyarakat Indonesia, terutama masyarakat berekonomi lemah yang hidup dipedesaan dan lingkungan kumuh di perkotaan. Penyakit infeksi kulit sering dijumpai pada anak-anak, walaupun belum ada angka statistik yang membandingkan frekuensi penyakit umum dengan penyakit infeksi kulit pada anak-anak, namun dari berbagai poliklinik Dinas Kesehatan Kota dan Kabupaten didapatkan informasi bahwa sekitar 20\% kasus yang dilaporkan adalah penyakit infeksi kulit (Budijanto, 1997). Penyakit infeksi kulit yang sering ditemukan pada masyarakat adalah penyakit infeksi bakteri (pioderma) dan penyakit infeksi jamur (mikosis superfisialis).Dalam penelitian ini diutamakan pada pencarian obat alternatif yang terjangkau untuk penyakit infeksi kulit yang disebabkan oleh bakteri atau pioderma, dan senyawa turunan calkon dapat menjadi solusi masalah tersebut.

Senyawa calkon merupakan salah satu senyawa metabolit sekunder golongan flavonoid yang berpotensi sebagai antibakterial, anti jamur, dan anti-ulcer / sejenis penyakit kulit, bisul (Prasad et al, 2006). Senyawa ini sangat menarik dalam kaitannya dengan penggunaannya sebagai material awal dalam sintesis berbagai jenis senyawa heterosiklik seperti senyawa 
pirazolin, pirimidin, sikloheksanon yang kaya dengan aktifitas biologis.Senyawa calkon ini dapat diperoleh dengan cara isolasi dari tumbuhan, namun untuk memperolehnya, terdapat beberapa kelemahan antara lain jumlahnya di alam yang terbatas dan persentasenya dalam tumbuhan juga kecilsekitar 3-5\%, variasi strukturnya relatif sedikit, serta membutuhkan biaya yang cukup mahal dan waktu yang cukup lama untuk mengisolasinya. Bertolak dari hal tersebut, maka didapatkan suatu/solusi yang dapat meminimalisir segala kekurangan dalam proses isolasi itu yaitu dengan cara sintesis kimia.Karena sintesis merupakan upaya terbaik untuk menyiapkan senyawa calkon dan turunannya dengan jumlah dan variasi struktur sesuai dengan yang dikehendaki

Hal ini merupakan salah satu pendorong bagi kami untuk mengembangkan atau merekayasa molekul calkon baik untuk mempelajari sifat fisiko-kimianya atau untuk kepentingan terapeutik. Salah satu metoda sintesis untuk membuat senyawa turunan calkon adalah melalui kondensasi Aldol dari suatu keton aromatik dan aldehid aromatik baik dalam kondisi basa maupun asam. Metoda ini dikenal ramah lingkungan (Green Chemistry) karena menggunakan bahan kimia berbahaya yang relatif kecil.

Dewasa ini, penemuan penelitian berupa senyawa bioaktif dapat dikembangkan menjadi senyawa medisinal unggulan yang bernilai ekonomi tinggi. Penelitian ini sangat penting mengingat di negara maju alur pikir teknologi kesehatan saat ini tidak lagi menggunakan senyawa kimia umum, namun pencarian senyawa kimia alami tunggal atau senyawa murni menjadi prioritas.

Pada penelitian terdahulu telah berhasil mensintesis senyawa turunan calkon yaitu (E)-1-(naftalen-1-il)-3-(naftalen)prop-2-1-on (A),yang disintesis dari 1-acetyl naftalene dengan 2- nafataldehid. Untuk itu perlu dilakukan uji lanjutan untuk menentukan khasiat yang tepat dari senyawa hasil sintesis ini dengan melakukan serangkaian uji aktifitas antibakteri dan uji aktivitas antijamur dengan penentuan konsentrasi hambat minimum dari senyawa hasil sintesis dan kesetaraannya dibandingkan antibakteri pembanding.

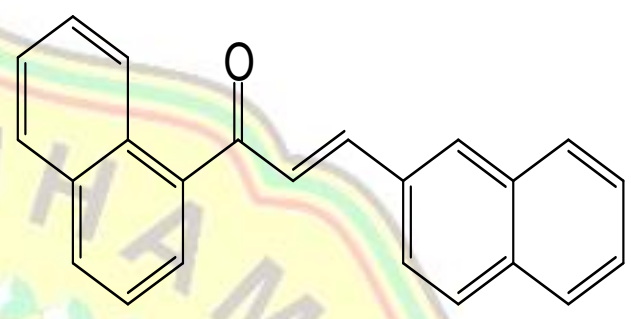

Senyawa calkon (E)-1-(naftalen-1-il)-3(naftalen)prop-2-1-on atau Senyawa (A)

Selama ini penelitian tentang sintesis molekul organik di Indonesia relatif sedikit dibanding kajian tentang isolasi bahan alam. Hal ini bertolak belakang dengan perkembangan global dimana kajian transformasi gugus fungsi dan sintesis merupakan pusat pengembangan ilmu kimia organik dan terbukti dengan banyaknya hadiah nobel yang diberikan untuk bidang ini. Disamping itu akhir-akhir ini kecenderungan global adalah bagaimana memperoleh molekul dalam jumlah yang banyak dengan waktu yang singkat. Hal ini yang mendasari pengembangan ilmu kimia kombinatorial yang tidak saja populer bagi kalangan peneliti akademik juga sangat pesat perkembangannya pada industri obat-obatan. Dalam penelitian ini, kami mencoba menggunakan pendekatan kimia kombinatorial dengan harapan dapat dengan mudah menemukan senyawa kimia potensial yang dapat digunakan sebagai formula obat. Sehingga dapat dilakukan banyak uji aktivitas untuk menemukan obat yang betulbetul stabil dan memiliki efek samping 
sangat kecil, terutama untuk antibiotik dan suplemen antioksidan.

Adapun tujuan dari Penelitian ini adalah untuk mengetahui kadar hambat Minimum (KHM) dari senyawa calkon calkon (E)-1(naftalen-1-il)-3-(naftalen)prop-2-1-on atau Senyawa (A) terahdap bakteri gram positif, bakteri gram negative dan jamur candida albicans

\section{METODOLOGI PENELITIAN}

\section{Alat dan Bahan}

Bahan yang digunakan adalah: agar NA, agar NB, bakteri Staphylococcus aureus, Escherichia coli, Candida albicans, $\mathrm{NaCl}$ 0,9 $\%$, asam sulfat $\left(\mathrm{H}_{2} \mathrm{SO}_{4}\right)$ pekat dan encer,kloroform $\left(\mathrm{CHCl}_{3}\right)$, asam klorida $\left(\mathrm{HC}_{1}\right) \quad 2 \mathrm{~N}$ dan pekat, etanol p.a $\left(\mathrm{CH}_{3} \mathrm{CH}_{2} \mathrm{OH}\right)$, larutan DPPH, L-ascorbic acid,methanol p.a $\left(\mathrm{CH}_{3} \mathrm{OH}\right)$, methanol teknis, amoxsan, Ketoconazol, natrium hidroksida $(\mathrm{NaOH}) 1 \mathrm{~N}$, air suling $\left(\mathrm{H}_{2} \mathrm{O}\right)$, Water pepton (WP), Potato Dextrosa Agar dan indikator $\mathrm{pH}$ universal. Alat-alat yang digunakan adalah: alat gelas, spatula, oven, kulkas, neraca analitik, Magnetic stirer, cawan petri, kawat ose, water shaker, incubator dan otoklaf.

\section{Prosedur Kerja}

\section{a). Uji Antibakteri}

Bakteri-bakteri yang digunakan untuk uji aktivitas adalah bakteri Escherichia coli dan Staphylococcus aureus. Sebelum dipakai untuk uji aktivitas, terlebih dahulu harus dilakukan peremajaan terhadap bakteribakteri tersebut. Media NB yang telah dibuat dimasukkan kedalam tabung reaksi masingmasing $10 \mathrm{~mL}$ dan disterilisasi. Jarum ose yang telah disterilisasi dengan pembakaran digoreskan pada agar miring yang berisi biakan bakteri dan selanjutnya dicelupkan ke dalam tabung reaksi yang berisi media NB. Tabung ditutup dengan kapas kemudian diinkubasi dalam inkubator pada suhu $37^{\circ} \mathrm{C}$ selama 24 jam. Biakan bakteri siap dipakai untuk uji bioaktivitas.

Pengujian aktivitas antibakteri dilakukan dengan metode difusi agar menggunakan silinder-silinder steril. Ke dalam cawan petri steril dimasukan suspensi bakteri sebanyak $15 \mu \mathrm{L}$ kemudian dimasukan media agar Nutrient Broth (NB) yang masih cair sebanyak $15 \mathrm{~mL}$ dan media dibiarkan memadat pada suhu kamar. Setelah memadat buat lubang berdiameter $6 \mathrm{~mm}$ dengan menggunakan silinder logam, kemudian masukan sampel calkon (A) sebanyak $10 \mu \mathrm{L}$ larutan uji dengan variasi konsentrasi di lubang yang dibuat. Kemudian diinkubasi pada suhu $37^{\circ} \mathrm{C}$ selama $16-18$ jam. Adanya daerah bening disekeliling lubang menunjukkan adanya aktivitas antibakteri.(Niwa, 1997)

\section{b). Uji Antifungal}

Jamur yang digunakan untuk uji aktivitas adalah jamur candida albicans. Sebelum dipakai untuk uji aktivitas, dahulu harus dilakukan peremajaan terhadap jamur tersebut.

Media water pepton (WP) yang telah dibuat dimasukkan kedalam tabung reaksi masing-masing $10 \mathrm{~mL}$ dan disterilisasi. Jarum ose yang telah distreilisasi dengan pembakaran digoreskan pada agar miring yang berisi biakan jamur dan selanjutnya dicelupkan ke dalam tabung reaksi yang berisi media NB. Tabung ditutup dengan kapas, kemudian diinkubasi dalam incubator pada suhu $37^{\circ} \mathrm{C}$ selama 24 jam. Biakan mikroba siap dipakai untuk uji bioaktivitas.

Kedalam cawan petri yang sudah disterilisasi, dimasukkan $1 \mathrm{~mL}$ larutan WP yang berisi jamur (Candidaalbicans). Selanjutnya kepada masing-masing petridis ditambahkan $20 \mathrm{ml}$ PDA (Potato Dekstrosa Agar) dan digoyang-goyang agar mikrobanya tersuspensi merata. Media PDA dibiarkan memadat, kemudian diletakkan cakram 
(diameter $6 \mathrm{~mm}$ ) yang telah ditetesi sampel senyawa A yang akan diuji dengan variasi konsentrasi sampel $10 \mu \mathrm{g} /$ disk dan $30 \mu \mathrm{g} /$ disk dalam dimetilsulfoksida (DMSO). Ketoconazole digunakan sebagai obat standar untuk skrining antijamur dibuat dengan konsentrasi $30 \mu \mathrm{g} /$ disk. DMSO digunakan sebagai kontrol negatif. Cawan petri kemudian diinkubasi didalam incubator pada suhu $37^{\circ} \mathrm{C}$ dengan membalikkan cawan petri. Diameter daerah bening disekitar kertas cakram diukur setelah cawan petri tersebut diinkubasi selama 24 jam.

\section{HASIL DAN PEMBAHASAN}

Uji aktivitas antibaktericalkon (E)-1(naftalen-1-il)-3-(naftalen)prop-2-1-on atau Senyawa (A) terhadap bakteri Staphylococcus aureus, Escherichia coli dan terhadap jamur Candida albicans dengan menggunakan metode difusi agar. dengan konsentrasi sampel, $10 \mu \mathrm{g}$ g/disk. Untuk uji anti bakteri, Amoxan dengan konsentrasi 10 $\mu \mathrm{g} /$ disk digunakan sebagai pembanding dan DMSO sebagai kontrol negatif, sedangkan untuk uji anti jamur digunakan Ketoconazole dengan konsentrasi $10 \mu \mathrm{g} /$ disk digunakan sebagai pembanding dan DMSO sebagai kontrol negatif. Hasil uji aktivitas antibakteri ditampilkan pada Tabel 1.

\section{Tabel 1.}

Hasil uji aktivitas antimikroba calkon (E)-1-

(naftalen-1-il)-3(naftalen)prop-2-1-on (A)

\begin{tabular}{|c|c|c|c|c|c|}
\hline \multirow{2}{*}{ No } & \multirow{2}{*}{ Senyawa } & \multirow{2}{*}{$\begin{array}{c}\text { Konsen } \\
\text { trasi } \\
\mu \mathrm{g} / \text { disk }\end{array}$} & \multicolumn{3}{|c|}{$\begin{array}{c}\text { Diameter hambatan } \\
(\mathbf{m m})\end{array}$} \\
\hline & & & $\begin{array}{c}E . \\
\text { coli }\end{array}$ & $\begin{array}{c}\text { S.aure } \\
\text { us }\end{array}$ & $\begin{array}{c}\text { C.albic } \\
\text { ans }\end{array}$ \\
\hline 1 & $\begin{array}{l}\text { Calkon } \\
\text { (A) }\end{array}$ & 10 & 0 & 0 & 17.08 \\
\hline 2 & Amoxan & 10 & $\begin{array}{l}23 . \\
51\end{array}$ & 8.36 & - \\
\hline 3 & $\begin{array}{l}\text { Ketocon } \\
\text { azole }\end{array}$ & 10 & - & - & 20.88 \\
\hline
\end{tabular}

Keterangan: pemetesan kedalam cakram $10 \mu \mathrm{L}$
Hasil uji aktivitas antibakteri menunjukkan bahwa calkon (E)-1-(naftalen1-il)-3-(naftalen)prop-2-1-on (senyawa A) tidak aktif terhadap bakteri uji, tapi aktif terhadap jamur uji. Data memperlihatkan aktivitas anti jamur senyawa calkon (E)-1(naftalen-1-il)-3-(naftalen)prop-2-1-on (senyawa A) cukup baik mendekati standar Ketoconazole dengan diameter hambatan terhadap Candida albicans sebesar 17,08 mm, terlihat (Tabel 1., Gambar 2.).

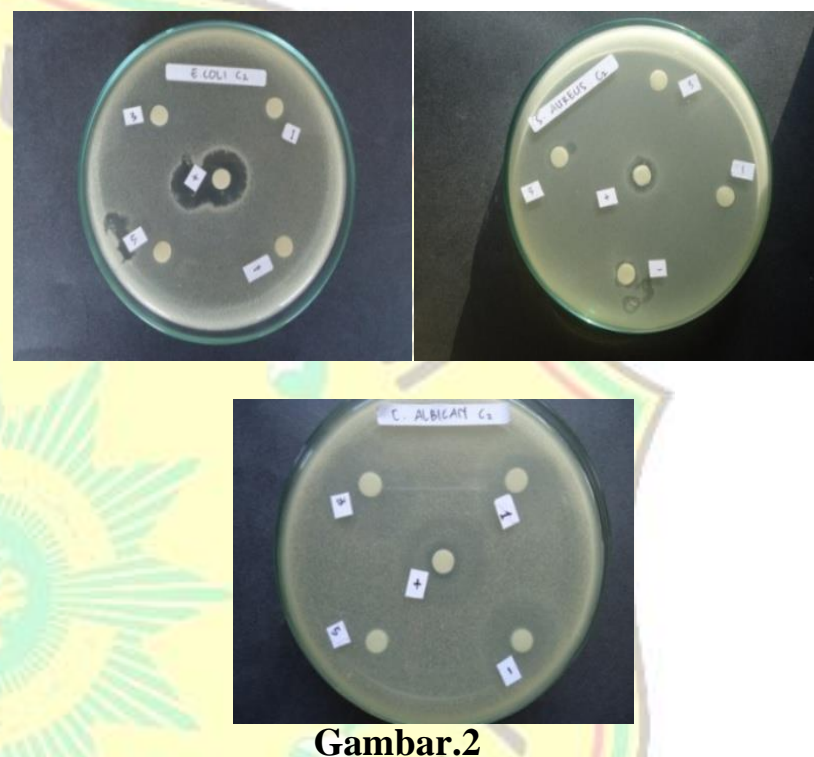

Hambatan antimikroba calkon (E)-1-(naftalen-1il)-3-(naftalen)prop-2-1-on (senyawa A) terhadap koloni Escherichia coli

(a),Hambatan antibakteri calkon (E)-1-(naftalen-1-il)3-(naftalen)prop-2-1-on (senyawa A) koloni Staphylococcus aureus

(b), Hambatan antibakteri calkon (E)-1-(naftalen-1-il)3-(naftalen)prop-2-1-on (senyawa A) terhadap koloni candida albicans

\section{Pembahasan}

\section{Uji aktivitas antibakteri}

Uji aktivitas antibakteri terhadap senyawa A dilakukan dengan metode difusi agar pada konsentrasi $10 \mu \mathrm{g} /$ disk. Senyawa tersebut dilarutkan dengan DMSO. Dalam hal ini, DMSO digunakan sebagai pelarut dan juga sebagai kontrol negatif. Amoxan digunakan sebagai antibiotik pembanding 
dibuat dengan konsentrasi $10 \mu \mathrm{g} /$ disk. Pemilihan konsentrasi larutan uji ini mengacu pada penelitian yang telah dilakukan oleh Kaisar dkk (2011). Pada kertas cakram, senyawa diteteskan sebanyak $10 \mu \mathrm{l}$ menggunakan pipet mikro dengan konsentrasi $10 \mu \mathrm{g} /$ disk, lalu ditunggu hingga kering. Kertas cakram yang telah ditetesi senyawa diletakkan pada media agar yang telah memadat. Tujuan pengeringan larutan ini adalah agar pelarutnya menguap dan sampel terserap di kertas cakram, sehingga sampel tersebut yang diharapkan memiliki aktivitas sebagai antibakteri, bukan pelarut yang digunakan.

Mikroba yang diuji terdiri dari bakteri dan jamur, bakteri uji yang digunakan ada dua bakteri yaitu bakteri Gram positif (S. aureus) dan bakteri Gram negatif (E. coli). Kedua bakteri tersebut dipilih karena bakteri tersebut lazim digunakan pada uji aktivitas biologi dan mendapatkan sediaanya agak lebih mudah, serta pada umumnya bakteri tersebut juga merupakan penyebab beberapa penyakit dan menginfeksi manusia.

Senyawa calkon A mengandung gugus etilen keto (-CO-CH=CH-) yang reaktif (Jayapal dan Sreedhar, 2010). Gugus etilen keto (keton $\alpha, \beta$ tak jenuh) pada senyawa calkon tersebut diketahui bertanggung jawab terhadap sifat antibakteri senyawa calkon (Lahtchev dkk, 2008). Selain itu, sifat antibakteri calkon juga tergantung pada substituen yang terikat pada kedua cincin aromatik calkon, seperti gugus $\mathrm{Cl}$ dan $\mathrm{Br}$. Gugus halogen seperti $\mathrm{Cl}$ dan $\mathrm{Br}$ sebelumnya telah dikenal mempunyai aktivitas antibakteri yang cukup baik (Prasad dkk, 2006)

Daya hambat yang dihasilkan senyawa calkon A terhadap bakteri Gram positif dan terhadap bakteri Gram negative menunjukkan tidak aktif. Hal ini disebabkan karena senyawa calkon A mempunyai molekul yang besar dimana Gugus etilen keto (keton $\alpha, \beta$ tak jenuh) pada senyawa calkon tidak dapat efektif untuk dapat bereaksi dengan dinding sel dari bakteri. Senyawa calkon A juga tidak mempunyai substituent yang bisa mendorong pergerakan elektronnya. Hal tersebut dapat dilihat pada tidak terdapatnya zona bening yang dihasilkan oleh senyawa A terhadap bakteri uji. Sementara amoxan memiliki aktivitas lumayan bagus pada E.Coli dengan diameter zona bening yang dihasilkan yaitu $23.51 \mathrm{~mm}$ dan zona bening dari $S$. aureus yang dihasilkan, yaitu $8,36 \mathrm{~mm}$. Jika diameter zona bening atau zona hambat lebih besar dari $20 \mathrm{~mm}$ berarti senyawa uji memiliki aktivitas kuat, diameter hambat 16-20 mm memiliki aktivitas sedang, diameter hambat 10-15 mm memiliki aktivitas lemah, sedangkan diameter hambat yang lebih kecil dari $10 \mathrm{~mm}$ memiliki aktivitas sangat lemah (Saxena dan Gomber, 2008). Daya hambat Senyawa calkon A tidak kelihatan dibandingkan dengan daya hambat antibiotik amoxan pada konsentrasi larutan uji yang sama.

Daya hambat yang dihasilkan senyawa calkon A terhadap jamur candida albicans menunjukkan aktivitas yang baik. Hal ini disebabkan senyawa calkon A dapat mengganggu sel jamur, karena adanya ergosterol didalam membran sel jamur, dimana ergosterol merupakan komponen yang sangat penting, sangat mudah diserang oleh antijamur turunan polien. Kompleks polien ergosterol yang terjadi dapat membentuk suatu pori yang permeable terhadap konstituen yang essensial bagi sel jamur, sehingga konstituen tersebut keluar sel dan mengakibatkan kematian bagi sel jamur tersebut (Lahtchev, dkk.2008). Senyawa calkon A adalah senyawa turunan polien (mempunyai ikatan rangkap dua yang banyak), sehingga dia mempunyai aktivitas yang baik terhadap jamur uji, terbukti dengan 
daerah zona bening terhadap candida albicans yaitu $17.08 \mathrm{~mm}$. Tapi masih dibawah senyawa standar yang daerah zona beningnya mencapai $20,88 \mathrm{~mm}$.

\section{KESIMPULAN}

Berdasarkan hasil penelitian yang telah dilakukan, maka dapat diambil kesimpulan diantaranya sebagai berikut:

1. Senyawa calkon (E)-1-(naftalen-1-il)-3(naftalen)prop-2-1-on (senyawa A) tidak memiliki aktivitas terhadap bakteri gram positif maupun bakteri gram negatif.

2. Senyawa calkon (E)-1-(naftalen-1-il)-3(naftalen)prop-2-1-on (senyawa A) memiliki aktivitas antijamur yang baik pada konsentrasi $10 \mu \mathrm{g} /$ disk dengan diameter zona hambat yang dihasilkan yaitu sebesar 17, $08 \mathrm{~mm}$.

\section{DAFTAR PUSTAKA}

Achanta, G.; Modzelewska, A.; Feng, L.; Khan, SR. and Huang, P. (2006). "Boronic-Chalcone Derivative Exhibits Potent Anticancer Activity through Inhibition of the Proteasome". Molecular Pharmacol,70, 426-433

Ansel H.C. (1989). Pengantar Bentuk Sediaan Farmasi, Edisi 4, Penerbit Universitas Indonesia, Jakarta, 31-45

Budijanto, S.K., (1997), Penelitian Prevalensi Pitiariasis versicolor pada murid Sekolah Dasar (SD) di Kelurahan utan kayu utara, Medica, 10(23), 1 2.

Choi, D.H and Cha, Y.K. (2002 a).”Optical anisotropy of polyimide and polymethacrylate containing photocrosslinkable chalcone group in the side chain under irradiation of a linearly polarized UV light". Bull. Korean Chem. Soc, 23, 469-476
Choi, D.H and Cha, Y.K. (2002 b)."Photoalignment of low-molecular mass nematic lquid crystal on photochemically bifungsional chalcone-epoxy film by irradiation of a linearly polarized UV light". Bull. Korean Chem. Soc, 23, 587-592.

Dey, P.M., and Harborne, J.B. (1991). Methode in Plant Biochemistry, Vol. 6, Academic Press, San Diego, 2-55.

Hayashi, A.; Gillen, A.; C. Loot, J.R (2000).“ Effects of daily oral administration of quercetin chalcone and modified citrus pectin on implanted colon-25 tumor growth in balb-c mice. Alternative Medicine Review. 6, 546552.

Jayapal, M.R. dan Sreedhar, N.Y. 2010. Anhydrous K2CO3 as Catalyst for the synthesis of Chalcones under Microwave Irradiation. Journal of Pharmaceutical Science and Research. 2(10): 644-647.

Jayapal, M.R., Prasad, K.S., dan Sreedhar, N.Y. 2010. Synthesis and Characterization of 2,6-Dihydroxy Substituted Chalcones Using PEG400 as a Recyclable Solven. Journal of Pharmaceutical Science and Research. 2(8): 450-458.

Jawet, M. and Adelberg. (1995). Mikrobiologi Kedokteran, Edisi XX, Terjemahan Edi Nugroho dan Maulany, R.F EGC, Jakarta, 608-614. Kim, Y.H.; Kim, J.; Park, H. and Kim, H.P. (2007). "Anti-inflammatory Activity of the Synthetic Chalcone Derivatives: Inhibition of Inducible Nitric Oxide Synthase-Catalyzed Nitric Oxide Production from Lipopolysaccharide-Treated RAW 264.7 Cells". Biol. Pharm. Bull. 30, 1450-1455 
Kobkeatthawin, T., Chantrapromma, S., Saewanb, N., dan Func H.K,. 2011. (E)-1-(4-Aminophenyl)-3(naphthalen-2-yl)prop-2-en-1-one. J. Acta Cryst.67, 1204-1205

Lahtchev, K.L., Batovska, D.I., Parushev, St.P., Ubiyvovk, V.M., dan Sibirny, A.A. 2008. Antifungal Activity of Chalcones: A Mechanistic Study using Various Yeast Strains. European Journal of Medicinal Chemistry. 43: 2220-2228.

Lee, Y.S.; Lim, S.S.; Shin, K.H.; Kim, Y.S.; Ohuchi, K. and Jung, S.H. (2006). "Anti-angiogenic and Anti-tumor Activities of 2'-Hydroxy-4methoxychalcone". Biol. Pharm. Bull. 29. 1028-1031

Palleros, D.R. (2004).”Solvent free synthesis of chalcones". J. Chem. Ed, 81, 13451347.

Prasad, Y.R.; Kumar, P.R.; Deepti, C.A.; Ramana, M.V. (2006). "Synthesis and antimicrobial activity of some novel chalcones of 2-hydroxy-1acetonapthone and 3-acetyl coumarin". E-Jornal of Chemistry, 3, 236-241.

Tsukiyama, R.I.; Katsura, H.; Tokuriki, N.; Kobayashi, M. (2002). ”Antibacterial Activity of Licochalcone A against Spore-Forming Bacteria”. J. American Society for Microbiology.45. 1226-1230

Yun, J.; Kweon, M.; Kwon, H.; Hwang, J. and Mukhtar, H. (2006)." Induction of apoptosis and cell cycle arrest by a chalcone panduratin A isolated from Kaempferia pandurata in androgenindependent human prostate cancer cells PC3 and DU145". Carcinogenesis. 27, 1454-1464.

Zamri, A., Eryanti, Y., Jasril. 2007. "Sintesis dan aktivitas antimikroba 3 analog calkon. 